\title{
Earnings Management and Fraudulent Financial Reporting: The Malaysian Story
}

\author{
Rashidah Abdul Rahman \\ King Abdul Aziz University, Jeddah, Saudi Arabia \\ Saliza Sulaiman \\ Universiti Teknologi MARA (UiTM), Shah Alam, Malaysia \\ Eiman Saleh Fadel \\ King Abdul Aziz University, Jeddah, Saudi Arabia \\ Soheil Kazemian \\ Universiti Teknologi MARA (UiTM), Shah Alam, Malaysia
}

\begin{abstract}
Earnings management research has a long and rich history. The agency conflict, incentives, rationalization, opportunity plus having the capability among the managers to manipulate the financial statements lead them to commit fraud. The loopholes in the standards or the deviation from real operational activities promote this situation to prolong. In relation to this issue, this study examines the earnings management behavior among fraud firms in Malaysia. Further, this study examines the relationship between accruals earnings management as a proxy variable for discretionary accruals and real earnings management as the proxy variable for discretionary cash flow. Sample of 57 alleged fraud firms was selected based on the fraudulent financial reporting offences announced in Bursa Malaysia website. The sample data are collected from public firms which committed fraud from 2001 to 2013. This study found a significant negative relationship between accruals earnings management and real earnings management among the fraud firms in Malaysia suggesting that these firms aggressively manage earnings downwards or upwards essentially to avoid regulators scrutiny apart from aiming to achieve personal incentives. The study significantly finds evidence that fraud firms manage earnings on a sequential basis between accruals earnings management and real earnings management prior to fraud year. The findings indicate that firms opt for real earnings management and make full use of its distinguished features of not easily traceable to continue managing earnings immediately subsequent to fraud year. This study may assist regulators, auditors, and policymakers to curb earnings management patterns that have high likelihood of becoming part of fraud antecedent.
\end{abstract}

Keywords: accrual earnings management, real earnings management, discretionary cash flow from operation and discretionary accruals

Rashidah Abdul Rahman, full professor, Faculty of Economics and Administration, King Abdul Aziz University. Email: rabdulwahid@kau.edu.sa.

Saliza Sulaiman, lecturer, Faculty of Accountancy, Universiti Teknologi MARA (UiTM).

Eiman Saleh Fadel, accounting lecturer, Faculty of Economics \& Administration, King Abdul Aziz University.

Soheil Kazemian, research fellow, Accounting Research Institute (ARI), Universiti Teknologi MARA (UiTM). 


\section{Introduction}

In the field of earnings management, researchers suggest two alternative ways to manage earnings: accrual earnings management and real earnings management (Roychowdhury, 2006; Matsuura, 2008; Bartov \& Cohen, 2009). Real earnings management is customarily accomplished through changes in the firm's underlying operations distinguished from accruals earnings management that is accomplished through the choice of accounting methods used (Gunny, 2005). Among reasons why firms opt for real earnings management are due to the adverse consequences of managing earnings through accruals method and the nature of the reversal itself. Those firms that have the obligations to meet the earnings target for consecutive years have limited or no choice but to continue accruing the expenditure even the one created earlier have yet to be reversed. Eventually, these firms might choose to commit fraud to offset the accruals. The precariousness and volatility of accruals earnings management require the earnings manipulators or fraudsters to vigorously search for more complex and sophisticated accounting or operational methods or combination of both to manage their earnings. These involve changes in underlying operations to ensure that the earnings expectations are met with the hope of not being easily detected or never being traced. Thus, real earnings management is expected to fulfill this gap.

Real earnings management enables managers to meet short-term earnings targets. However, they are unlikely to increase long-term firm value mainly because the deviations from real activities have abundant impact on future cash flows (Cohen \& Zarowin, 2010). For example, the introduction of lenient credit term may increase sales tremendously in current year but slow collection due to leniency will greatly impact future cash flow even though the earnings increased in the current year due to sales increased.

Despite the increasing interest in the relationship between accruals earnings management and real earnings management among scholars in many countries (Lee \& Swenson, 2011), there are no in-depth studies related to real earnings management or empirical studies to test both accruals and real earnings management among fraud firms in Malaysia. Hence, this study analyses the real earnings management activities among fraud firms in three years prior to fraud year and immediately subsequent to fraud year for those firms convicted of issuing fraudulent financial reporting in Malaysia. This study further observes the relationship between real earnings management and accruals earnings management among fraud firms and the likelihood of those earnings management activities will lead the respective firms to commit fraudulent financial reporting.

This research contributes to the literature on fraud antecedents among defrauded organizations in Malaysia by providing evidence on the relation between accruals earnings management and real earnings management among fraud firms in Malaysia in prior- and post-fraud years. This research also intends to add an understanding about the types of earnings management among fraud firms in Malaysia which has the potential to improve auditors' and regulators' ability to detect this type of fraud especially in developing countries like Malaysia.

The following sections are organised as follows: Section 2 highlights the literature review and hypotheses development; Section 3 covers the research methodology of the study; Section 4 elaborates the findings and Section 5 concludes the study.

\section{Literature Review and Hypotheses Development}

Perols and Lougee (2011) found that fraud is significantly higher for firms that have previously managed earnings. Zhao and Chen (2008) revealed that managers will not resort in various value-destroying activities (earnings management or fraudulent financial reporting) if there is less pressure. This is in line with the fraud triangle theory which indicates that financial statement fraud occurs as a result of pressures to meet internal and 
external expectations, opportunity, and rationalization (W. S. Albrecht, C. C. Albrecht, C. O. Albrecht, \& Zimbelman, 2009). Further, the fraud diamond theory argues that opportunity opens the doorway to fraud, and incentive and rationalization can draw the person toward it, but the person must have the capability to recognize the open doorway as an opportunity and to take advantage of it (Wolfe \& Hermanson, 2004). Fraudsters must have the ability to comprehend standards and operations to manage earnings aiming to achieve the earnings target and based on these capabilities, fraudulent activities are possible to commit.

Apart from this fraud risk factor, earnings management arises from agency frictions, possibly when managers want to maximize their private benefits or due to pressure to provide high-quality financial information to external stakeholders. They are constrained into managing earnings and later when the pressure heightens to achieve earnings target, the earnings quality is no longer the priority; instead, achieving their private benefits becomes their main goal. Later, when the performance of firms is the utmost concern, ample opportunity, capability, and pressure harmonizing with the rationalization will lead firms to commit fraud.

The results found in the studies by Roychowdhury (2006) in the US and Matsuura (2008) in Japan documented that managers use real earnings management and/or accruals earnings management to smooth earnings. Further study conducted by Perols and Lougee (2011) using a sample of 108 US fraud and non-fraud firms found that there is a significant positive relation between aggregated discretionary accruals three years prior to fraud year and fraud firms. However, they found a marginal significant relationship between real earnings management and fraud firms. Further analysis prior to fraud year indicates positive relations between real earnings management and fraud firms.

Similar to the argument by Taylor and $\mathrm{Xu}$ (2010) and based on the fraud triangle theory, it is anticipated that fraud firms in Malaysia opt for real earnings management due to constraints in their ability to inflate accruals, to avoid reporting losses, and to meet analyst earnings forecast. Hence, there is a significant negative relationship between accruals earnings management and real earnings management among alleged fraud firms in Malaysia.

Based on the above argument, we design the following hypotheses:

H1: There is a significant negative relationship between accruals earnings management and real earnings management among fraud firms in Malaysia.

$\mathrm{H} 2$ : There is a significant negative relationship between accruals earnings management and real earnings management among fraud firms in Malaysia prior to fraud year (three years prior to fraud year).

H3: There is a significant negative relationship between accruals earnings management and real earnings management among fraud firms in Malaysia immediately subsequent to fraud year.

\section{Sample Description and Data Collection}

The sample selection initially consists of 125 alleged fraud firms (firms with fraud and lawsuit revelation) in Malaysia, obtained from the website of Bursa Malaysia and Securities Commission of Malaysia (SC) for the period from 2001 to 2013. The fraud scandals varied which consist of submitting false information to the authorities, utilising firm's fraud for unapproved purposes, criminal breach of trust, falsification of annual report and being sued by the banks, disgruntled employee or supplier. By default, the first fraud year was determined by identifying the year when the fraud is committed or first occurred based on what was disclosed in the description of the offence. 
We subsequently filtered and removed firms who committed fraud more than once; financial firms such as banks, unit trusts and closed-end funds are excluded because of specialised and unique regulations and have different accruals behaviours as compared to other industries (Klein, 2002; Abdul Jalil \& Abdul Rahman, 2010); and firms with incomplete annual reports, leaving a final sample of 57 firms. Annual reports for active firms are collected for six years: four years prior to fraud year, fraud year, and immediately subsequent to fraud year ( $t$-4 until $t+1)$, with 342 fraud firm years in total.

\section{Measurement}

Accruals earnings management as a proxy variable for discretionary accruals is measured using Jones model as used in studies by Hasnan, Abdul Rahman, and Mahenthiran (2014) and Kothari, Leone, and Wasley (2005). To estimate the accruals earnings management, total accruals (TAC) are measured as the change in non-cash current assets minus the change in current liabilities excluding the current portion of long-term debt, minus depreciation and amortization, scaled by lagged total assets which are given as:

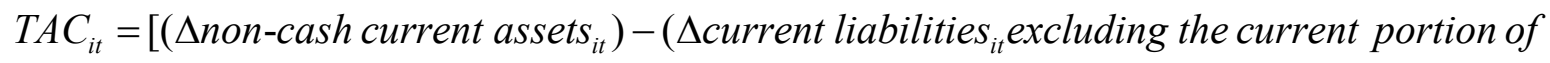

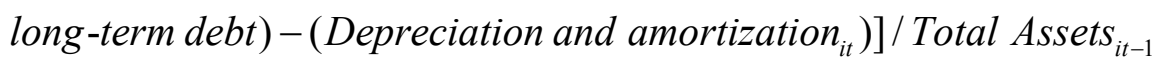

Then, based on the Jones model estimated cross-sectionally using all firm year observations for each industrial sector, the normal total accruals for each industry are calculated as follows:

$$
T A C_{i t}=\delta_{0}+\delta_{1}\left(1 / T A_{i t-1}\right)+\delta_{2} \Delta S A L E S_{i t}+\delta_{3} P P E_{i t}+\delta_{4} R O A_{i t}+v_{i}
$$

where:

$T A C_{i t}=$ Total accruals;

$T A_{i t-1}=$ Lagged total assets;

$\triangle S A L E S_{i t}=$ Change in sales scaled by $T A_{i t-1}$;

$P P E_{i t}=$ Net property, plant, and equipment scaled by $T A_{i t-1}$;

$R O A_{i t}=$ Net income in current year divided by total assets in the current year.

The coefficient estimates from Equation (1) are used to estimate the firm-specific normal accruals $\left(N A_{i t}\right)$ for our sample firms:

$$
N A_{i t}=\delta_{0}+\delta_{1}\left(1 / T A_{i t-1}\right)+\delta_{2} \Delta S A L E S_{i t}+\delta_{3} P P E_{i t}+\delta_{4} R O A_{i t}+v_{i}
$$

The residual $\left(v_{i t}\right)$ derived from the model is the earnings management $(A E M)$ as a proxy variable for discretionary accruals which could be derived from the following:

$$
A E M_{i t}=T A C_{i t}-N A_{i t}
$$

The measurement for real earnings management as a proxy variable for discretionary cash flow from operation has been proposed by Roychowdhury (2006). This variable is used to measure sales manipulation. Sales manipulation is defined as managers' attempt to temporarily increase sales during the year by offering price discounts or more lenient credit terms. It is expected that the real management activities will lead to lower current period cash flow and higher production cost and simultaneously causing a negative effect on the abnormal cash flow. Consistent with Roychowdhury (2006), the normal cash flow from operation is expressed 
as a linear function of sales and change in sales. To estimate this, we run the following cross-sectional regression for each industry and year as follows:

$$
C F O_{t} / T A_{t-1}=\alpha_{0}+\alpha_{1}\left(1 / T A_{t-1}\right)+\beta_{1}\left(\text { Sales }_{t} / T A_{t-1}\right)+\beta_{2}\left(\Delta \text { Sales }_{t} / T A_{t-1}\right)+\varepsilon_{t}
$$

where:

$C F O_{t} / T A_{t-1}=$ Cash flow from operations for firm $i$ at period $t$;

$T A_{t-1}=$ Assets at the end of the prior year;

Sales $_{t}=$ Net sales during year $t$;

$\Delta$ Sales $_{t}=$ Change in sales during year $t$, Sales $_{t}-$ Sales $_{t-1}$.

The coefficient estimates from Equation (2) are used to estimate the firm-specific normal cash flow from operation lagged of total assets $\left(R_{-} C F O_{t}\right)$ for our sample firms:

$$
R_{-} C F O_{t}=\alpha_{0}+\alpha_{1}\left(1 / T A_{t-1}\right)+\beta_{1}\left(\text { Sales }_{t} / T A_{t-1}\right)+\beta_{2}\left(\Delta \text { Sales }_{t} / T A_{t-1}\right)+\varepsilon_{t}
$$

Abnormal cash flow from operation is actual cash flow from operations $\left(C F O_{t}\right)$ lagged of total assets minus the normal level of cash flow from operation $\left(R_{-} C F O_{t}\right)$ using the coefficient from Equation (2). Based on the above measurement, we may now calculate real earnings management $(R E M)$ as follows:

$$
R E M=C F O_{t} / T A_{t-1}-R_{-} C F O_{t}
$$

A summary of variables and the measurement used in the study is presented in Table 1.

\begin{tabular}{|c|c|c|}
\hline Variables & Definition & Measurement \\
\hline \multicolumn{3}{|c|}{ Dependent variables } \\
\hline$A E M$ & $\begin{array}{l}\text { Accruals earnings management } \\
\text { (a proxy variable for discretionary accruals) }\end{array}$ & $\begin{array}{l}\text { Measured by performance matched } \\
\text { discretionary accruals based on Kothari et al. } \\
(2005) \text {. }\end{array}$ \\
\hline \multicolumn{3}{|c|}{ Independent variables } \\
\hline$R E M$ & $\begin{array}{l}\text { Real earnings management } \\
\text { ( a proxy variable for discretionary cash flow) }\end{array}$ & $\begin{array}{l}\text { Consistent with Roychowdhury (2006), Zang } \\
(2007) \text {, and Gunny (2005), real earnings } \\
\text { management is measured by employing a } \\
\text { simple model that detects abnormal changes in } \\
\text { a firm's underlying cash flow operational } \\
\text { activities. }\end{array}$ \\
\hline$I N S D$ & Percentage of inside directors & $\begin{array}{l}\text { The percentage of inside directors on the board } \\
\text { of directors. }\end{array}$ \\
\hline AUDITYPE & Type of auditors & $\begin{array}{l}\text { A dummy variable coded " } 1 \text { " if the auditor is } \\
\text { Big } 4 \text { and " } 0 \text { " if otherwise. }\end{array}$ \\
\hline$R O A$ & Return on assets & $\begin{array}{l}\text { Calculated using the formula of net income } \\
\text { before interest and tax over total current assets } \\
\text { for the current year. }\end{array}$ \\
\hline
\end{tabular}

Table 1

Summary of Variables and the Measurement

\section{Findings}

\section{Details of the Event Study}

Table 2 depicts the descriptive statistics of all the variables used in the study across the period of study commencing from 2011 to 2013 among alleged fraud firms in Malaysia. 
Table 2

Descriptive Statistics (Across All Years of 2001-2013) for All Variables $(N=342)$

\begin{tabular}{lllll}
\hline Variable & Minimum & Maximum & Mean & Std. deviation \\
\hline AEM & -0.504 & 0.450 & -0.008 & 0.123 \\
REM & -0.329 & 0.194 & -0.018 & 0.085 \\
\%INSD & 0.000 & 0.750 & 0.395 & 0.158 \\
AUDITYPE & 0.000 & 1.000 & 0.514 & 0.501 \\
ROA & -0.396 & 0.170 & -0.025 & 0.101 \\
\hline
\end{tabular}

Note. AEM is a proxy variable for discretional accruals estimated by Kothari et al.'s (2005) model; REM is a proxy variable for discretional cash flow from operations estimated by Roychowdhury's (2006) model; \%INSD is a variable for the percentage of inside directors; AUDITYPE is a dummy variable equal to " 1 " if the auditor was from Big 4 audit firms and " 0 " if otherwise; $R O A$ is net income over current year total assets.

The accruals earnings management's mean value of -0.008 in Table 2 indicates that on average fraud firms tend to manage their earnings downward, consistent with the study conducted by Matsuura (2008). Generally, the average real earnings management value from operations for fraud firms in Malaysia is -0.018 . This is consistent with Korean, Taiwanese, and Hong Kong listed firms having a negative mean value for real earnings management, $-0.0173,-0.0181$, and -0.0183 respectively (Lee \& Swenson, 2011).

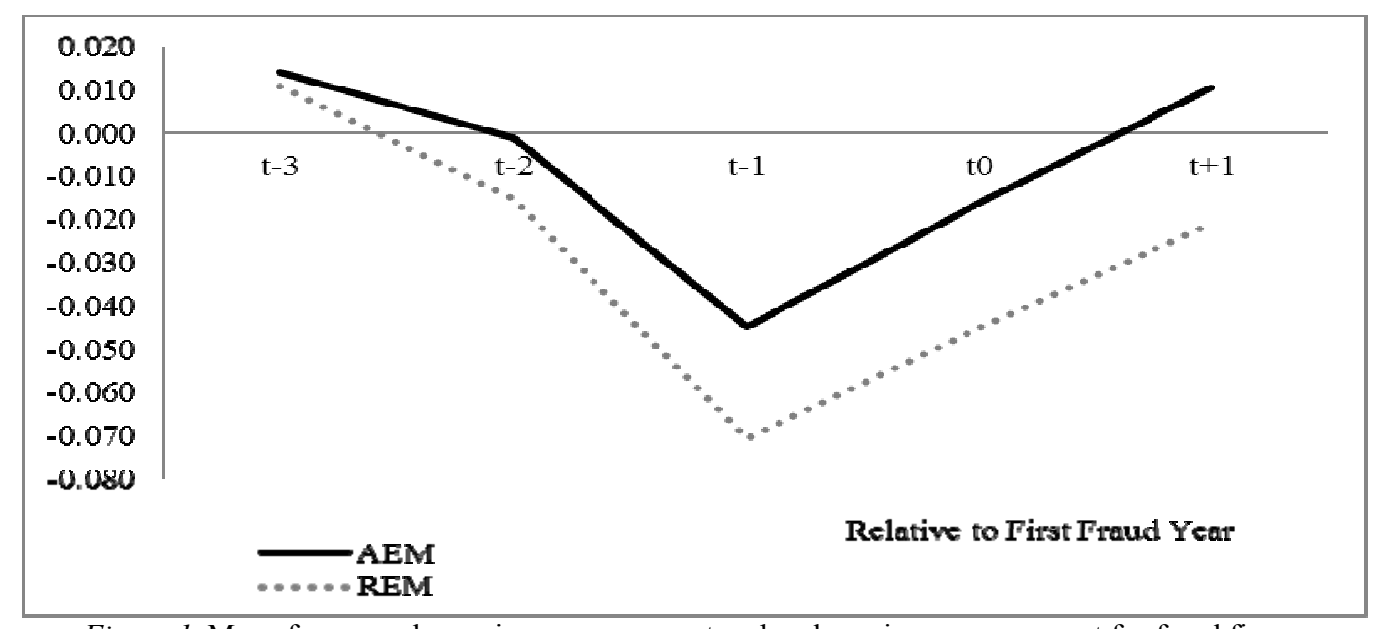

Figure 1. Mean for accruals earnings management and real earnings management for fraud firms.

Figure 1 depicted the average value of accruals earnings management and real earnings management for fraud firms in Malaysia. These fraud firms on average manage their earnings upwards and downwards prior to fraud years (three years prior to fraud year) and continue managing earnings immediately subsequent to fraud year. The result indicates that on average fraud firms in Malaysia manage their earnings way back prior to fraud years and continue managing their earnings subsequent to fraud year. They use both methods of earnings management: accruals and real earnings management methods. This finding is true in a situation for those firms who are aggressive and persistent in managing their earnings and find no way out to reverse their accruals, leading these firms with no choice but to commit fraud (Perols \& Lougee, 2011). Sequentially and simultaneously, firms opt for operational method of earnings management, that is, real earnings management, to smooth their earnings (Matsuura, 2008). The smoothening period can be seen in post-fraud year, indicating a positive mean of 0.010 for accruals earnings management, while these fraud firms continue managing earnings operationally (real earnings management) with a mean value of -0.031 . This is consistent with real earnings 
management behavior which indicates a higher value in fraud year and subsequent to fraud year. Aggressive earnings management leads to the likelihood of managers who resort to commit fraud to achieve objectives previously accomplished by managing earnings (Perols \& Lougee, 2011). Fraud firms are entrenched managing earnings even subsequent to fraud year possibly due to a lack of strict supervision and enforcement from regulators. Using one sample $t$-test, the result indicates that both accrual earnings management and real earnings management are very significant among alleged fraud firms in Malaysia. Hence, the results provide evidence that on average, listed alleged fraud firms in Malaysia aggressively manage their reported earnings either upwards or downwards prior to fraud year and continue to smoothen their earnings subsequent to fraud year $\left(t_{0}\right)$ through both accruals and real earnings management.

Table 3

Multiple Regressions Results Between Accruals Earnings Management and Real Earnings Management

\begin{tabular}{|c|c|c|c|c|c|c|}
\hline \multirow[t]{2}{*}{ Variable } & \multicolumn{2}{|c|}{$\begin{array}{l}\text { Across the years } \\
(2001-2013)\end{array}$} & \multicolumn{2}{|c|}{$\begin{array}{l}\text { Prior to fraud year } \\
(t-3, t-2, \text { and } t-1)\end{array}$} & \multicolumn{2}{|c|}{$\begin{array}{l}\text { Fraud year to post fraud year } \\
\left(\mathrm{t}_{0} \text { until } t+1\right)\end{array}$} \\
\hline & Coefficient & $t$-statistic & Coefficient & $t$-statistic & Coefficient & $t$-statistic \\
\hline Intercept & -0.031 & -1.426 & -0.041 & -1.835 & -0.015 & -0.374 \\
\hline REM & -0.358 & $-3.729^{* * *}$ & -0.450 & $-4.762^{* * *}$ & -0.231 & -1.155 \\
\hline$I N S D$ & 0.060 & 1.194 & 0.046 & 0.875 & 0.067 & 0.708 \\
\hline AUDITYPE & 0.008 & 0.514 & 0.015 & 0.954 & -0.005 & -0.156 \\
\hline$R O A$ & 0.458 & $5.729^{* * *}$ & 0.859 & $8.070^{* * *}$ & 0.290 & $2.257^{* *}$ \\
\hline Multiple $R$ & 0.411 & & 0.623 & & 0.266 & \\
\hline$R$-square & 0.169 & & 0.388 & & 0.071 & \\
\hline Adjusted $R$ square & 0.153 & & 0.369 & & 0.024 & \\
\hline$F$ value & $10.737^{* * *}$ & & $20.158^{* * *}$ & & 1.504 & \\
\hline$N$ & 342 & & 216 & & 148 & \\
\hline
\end{tabular}

Note. ${ }^{* * *}$ : Significant at the 0.01 level; ${ }^{* *}$ : Significant at the 0.05 level.

The multiple regression results in Table 3 depict that the coefficient of REM is negative $(-0.358)$ and statistically significant at $1 \%$ level, thus supporting $\mathrm{H} 1$ that there is a significant relationship between accruals earnings management and real earnings management practices. The result suggests that those firms who commit fraud decreased their accruals earning management practices and opt for real earnings management because it is perceived that real earnings management is less traceable by auditors and regulators mainly because the activities are of real operational basis even it does sacrifice the firms' future cash flows (Matsuura, 2008; Zhao \& Kapoor, 2011). This explains that accruals earnings management and real earnings management have a smoothing effect. The increase in accruals earnings management will reduce the earnings of fraud firms. This is mitigated by managing the earnings through real earnings management activities, increasing the earnings even when the cash flow is negative.

This is consistent with the findings of this study whereby the coefficient of return on assets is positive $(0.458)$ and statistically very significant at $1 \%$ level, suggesting that when firms manage their earnings based on accruals earnings management upwards, it is smoothened by real earnings management practices, the net income stabilized or increases, ultimately increasing the net income of the firms. The result of the study indicates the increase in return on assets of the fraud firms consistent with the increase in accrual earnings management and the negative relationship with the real earnings management. 
The regression Model 2 in Table 3 further exhibits stronger results compared to Model 1 with adjusted $R$ square of 0.369 , indicating that Pre_REM, Pre_\%INSD, Pre_AUDITYPE, and Pre_ROA explain $36.9 \%$ of the variation in accruals earnings management. The coefficient of $R E M$ is negative $(-0.450)$ and statistically significant at $1 \%$ level. The result is consistent with $\mathrm{H} 1$ and $\mathrm{H} 2$, suggesting that those firms who commit fraud decreased their accruals earning management practices and opt for real earnings management. However, it does sacrifice the firms' future cash flows (Zhao \& Kapoor, 2011) similar to Model 1. The result from this study contradicts with the result by Perols and Lougee (2011) which shows a significant relationship between accruals earnings management and fraud but marginally significant between real earnings management and fraud firms in the US.

Based on the analysis, fraud firms are aggressively managing their earnings using accruals and real earnings management three years prior to fraud year. Consistent with Model 1, Model 2 also indicates a positive (0.859) coefficient for return on assets and statistically significant at 1\% level. Both Models 1 and 2 are considered strong to support that there are significant negative (positive) relationships between accruals earnings management and real earnings management after taking into consideration all the relevant control adjustments.

The models considered are as follows:

Model 1:

$$
A E M=-0.031-0.358 R E M_{i t}+0.060 \%{I N S D_{i t}}+0.008 A U D I T Y P E_{i t}+0.458 R O A_{i t}+\varepsilon_{i t}
$$

Model 2:

$$
\begin{aligned}
& \text { Pre_AEM }=-0.041-0.450 \text { Pre } \text { REM }_{i t}+0.046 \text { Pre }_{-} \% I N S D_{i t}+0.015 \text { Pre } \text { AUDITYPE }_{i t} \\
& +0.859 \text { Pre } \_R O A_{i t}+\varepsilon_{i t}
\end{aligned}
$$

Model 3:

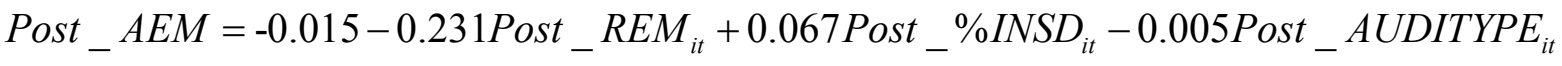

$$
\begin{aligned}
& +0.290 \text { Post_ROA }_{i t}+\varepsilon_{i t}
\end{aligned}
$$

Model 3 in Table 3 shows that the coefficient of REM is insignificantly related to accrual earnings in the fraud year and immediately subsequent to fraud year. Therefore, this study fails to support the null hypothesis and reject H3. Consistent with Models 1 and 2, the coefficient of return on assets for Model 3 is also positive (0.290) and statistically significant at $5 \%$ level. Possible explanation for this situation is that by manipulating earnings using accruals earnings management reduces the fraud firms' flexibility to manage earnings and opt for real earnings management. Real earnings management increases the earnings and ultimately increases the return on assets.

\section{Conclusion}

Based on the descriptive findings of the study, fraud firms in Malaysia aggressively manage their earnings downwards three years prior to fraud year. They continue managing their earnings immediately subsequent to fraud year. The pattern of earnings management differs between prior- and post-fraud years. Prior to fraud year, fraud firms manage earnings downwards via accruals earnings management and real earnings management on a sequential basis. This is consistent with the study by Eldenburg, Gunny, Hee, and Soderstrom (2011) who found that firms manage earnings downwards to avoid high tax burden. However, post-fraud year indicates that fraud firms tend to manage earnings on a complementary basis between accruals earnings management and real earnings management. 
This is possibly because, once they have committed fraud, they will be limited to continue managing their earnings, thus finding way out to reverse the accruals. In view of the nature of accruals earnings management that is easily detected by regulators, fraud firms opt to manage earnings operationally using real earnings management which is less traceable. This is evidenced by the increase in real earnings management practices in post-fraud year as compared to prior to fraud year.

This study also examined the relationship between real earnings management and accruals earnings management in prior- and post-fraud years after controlling for the percentage of inside directors, auditors' type, and return on assets. The regression result shows that there is a significant negative relationship between accruals earnings management and real earnings management prior to fraud year. The prediction that there is a significant negative relationship between accruals earnings management and real earnings management prior to fraud year is strongly supported by the findings of this study. However, the result from the regression shows that there is an insignificant relationship between accruals earnings management and real earnings management in fraud and immediately subsequent to fraud year.

The significant negative relationship in prior to fraud year indicates that fraud firms aggressively manage their earnings upwards prior to fraud year to reduce the high tax burden. Sequentially, fraud firms using real earnings management to manage their earnings downwards result in an increase in sales but having low cash flow from operations. This is supported by the significant positive relationship with the return on assets. Apparently, the normal cash flow is a function linear to sales. Irrespective of low cash flow from operations, the findings reveal that fraud firms manage their earnings to respond to incentive based compensation while having lesser risk of being detected by regulators.

Referring to the findings of the study, a possible explanation for the negative significant relationship between accruals earnings management and real earnings management is due to agency conflict and fraud diamond theory. Agency conflict arose when managers who possess more or better information about decision situation having conflict of interest find the best and securest alternative to manage earnings to achieve personal incentive. Real earnings management has been perceived as the most optimum and secured manner so far.

In a different scenario, one of the reasons for agency conflict is obvious, mainly due to pressure. The pressure could be from managing the company to meet the earnings target set by the board or company or pressure coming from the agents' own interest to achieve personal incentive. Pressure will lead managers to commit fraudulent behaviour and activities (Skousen, Smith, \& Wright, 2009). Pressure alone might not be a strong incentive to manage earnings aggressively. The opportunity and rationalization provide sort of motivation for the managers to go further and the most important is that a person must have the capability to recognize the open doorway as an opportunity and to take advantage of it (Wolfe \& Hermanson, 2004).

Fraud diamond theory explains this situation. Capability of a person making choice of earnings management pattern creates the choice of managing the earnings through accruals or real earnings management. Managing earnings upwards or downwards via accruals earnings management or real earnings management differs in terms of the cash flow impact from the operation. Capabilities are essential to manage earnings within the boundaries in order to swiftly cease or reverse their earnings management activities when required. Haphazard in managing earnings leads firms to commit fraud.

Based on the findings of the study, the relationship continues in the fraud year and immediately subsequent to fraud year but it is insignificant. One possible reason is that the proportion of reduction of accruals earnings management activities by fraud firms is no longer the same proportion with the increase in 
real earnings management activities in the fraud year and immediately subsequent to fraud year. Fraud firms continue managing earnings but opt for less traceable earnings management practises by auditors and regulators.

In conclusion, this study views that both accruals earning management and real earnings management lead managers to manage their earnings outside the Generally Accepted Accounting Principles (GAAP), initiated what we called as fraudulent financial reporting. These fraud firms aggressively managed their earnings prior to committing fraud and continued managing their earnings, even the proportion differs between accruals earnings management and real earnings management in fraud year and post-fraud year.

Fraud is a never-ending tragedy in business world. Regulators need to impose high penalty to prevent fraud firms from engaging in earnings management. Yaping (2006) concluded that if a reduction in accounting discretion induces managers to seek out other forms of earnings management, then any action taken by regulators to reduce accounting discretion will not be sufficient to eliminate earnings management. Ultimately, fraud will only be truly prevented when managers and employees understand and believe that ethics is an essential ingredient to a company's business.

This paper raises several questions for future research. One important issue is how managers choose between real activities manipulation and accruals manipulation when they have the flexibility to engage both. Comparison can be made with non-fraud firms to examine their earnings management pattern as compared to fraud firms. Financial distressed element should be included in selection of non-fraud firms since earnings management calculations are sensitive to these scenarios. Another area for future research is the timing of real activities manipulation. It is expected that the intensity to manipulate earnings occurs towards the end of the year as managers are seeking avenue to managed earnings through safer and less costly channel.

\section{References}

Abdul Jalil, A., \& Abdul Rahman, R. (2010). Institutional investors and earnings management: Malaysian evidence. Journal of Financial Reporting and Accounting, 8(2), 110-127.

Albrecht, W. S., Albrecht, C. C., Albrecht, C. O., \& Zimbelman, M. (2009). Fraud examination. South-Western Cengage Learning.

Bartov, E., \& Cohen, D. A. (2009). The "numbers game" in the pre- and post-Sarbanes-Oxley eras. Journal of Accounting, Auditing \& Finance, 24(4), 505-534.

Cohen, D. A., \& Zarowin, P. (2010). Accrual-based and real earnings management activities around seasoned equity offerings. Journal of Accounting and Economics, 50(1), 2-19.

Eldenburg, L. G., Gunny, K. A., Hee, K. W., \& Soderstrom, N. (2011). Earnings management using real activities: Evidence from nonprofit hospitals. The Accounting Review, 86(5), 1605-1630.

Gunny, K. (2005). What are the consequences of real earnings management. Hass School of Business, University of California, Working Paper.

Hasnan, S., Abdul Rahman, R., \& Mahenthiran, S. (2014). Determinants of fraudulent financial reporting: Evidence from Malaysia. Jurnal Pengurusan, 42, 103-117.

Klein, A. (2002). Audit committee, board of director characteristics, and earnings management. Journal of Accounting and Economics, 33(3), 375-400.

Kothari, S. P., Leone, A. J., \& Wasley, C. E. (2005). Performance matched discretionary accrual measures. Journal of Accounting and Economics, 39(1), 163-197.

Lee, N., \& Swenson, C. (2011). Earnings management through discretionary expenditures in the U.S., Canada, and Asia. International Business Research, 4(2), 257-266.

Matsuura, S. (2008). On the relation between real earnings management and accounting earnings management: Income smoothing perspective. Journal of International Business Research, 7(3), 63-77. 
Perols, J. L., \& Lougee, B. A. (2011). The relation between earnings management and financial statement fraud. Advances in Accounting, 27(1), 39-53.

Roychowdhury, S. (2006). Earnings management through real activities manipulation. Journal of Accounting and Economics, $42(3), 335-370$.

Skousen, C. J., Smith, K. R., \& Wright, C. J. (2009). Detecting and predicting financial statement fraud: The effectiveness of the fraud triangle and SAS No. 99. Advances in Financial Economics, 13, 53-81.

Taylor, G. K., \& Xu, R. Z. (2010). Consequences of real earnings management on subsequent operating performance. Research in Accounting Regulation, 22(2), 128-132.

Wolfe, D. T., \& Hermanson, D. R. (2004). The fraud diamond: Considering the four elements of fraud. The CPA Journal, 74, $38-42$.

Yaping, N. (2006). A different perspective of earnings management. Canadian Social Science, 2(4), 53-59.

Zang, A. (2007). The trade-off between real earnings management and accruals management. Working Paper, University of Rochester.

Zhao, J., \& Chen, C. (2008). An investigation of how to utilize products as a bridge to build relationships according to the $1 \mathrm{P}$ theory (in Chinese). Journal of Wuhan Commercial Service College, 03, 46-56.

Zhao, W., \& Kapoor, G. (2011). Detecting evolutionary financial statement fraud. Decision Support Systems, 50(3), $570-575$. 